\title{
Apoptosis Inducing Activity of Proteins Isolated from Muntingia Calabura Plant Root on Oral Cancer Cell Line: An In Vitro Study
}

\author{
Kumaran $\mathrm{C}^{1}$, Dinesha $\mathrm{R}^{2 *}$, Santhosh Kumar $\mathrm{N}^{3}$ \\ ${ }^{1}$ Professor, Department of Pathology, Oxford Medical College \& Research Centre, Bangalore, Karnataka, India \\ ${ }^{2}$ Scientific Officer, Adichunchanagiri Institute for Molecular Medicine (AIMM), AIMS- Central Research Laboratory, B.G. Nagara, Mandya, \\ Karnataka, India \\ ${ }^{3}$ Assistant Professor, Department of Biochemistry, Shridevi Institute of Medical Sciences, Tumkur, Karnataka, India
}

DOI: $10.36348 /$ SJPM.2019.v04i12.001 $\quad$ | Received: 20.11.2019| Accepted: 27.11.2019 | Published: 11.122019

*Corresponding author: Dr. Dinesha Ramadas

\section{Abstract}

Now days, research studies have concentrated on complementary (alternate) medicine in treating a large number of infectious and non-infectious diseases, including cancer. The attention of research now shifted towards alternative natural medicine and is being preferred to the toxic effects of the synthetic drugs that are used to treat such diseases. Studies have shown that many natural plant products like amygdalin extracted from apricots and almonds to have shown anticarcinogen effect on many types of cancers including oral cancer. Herein we made an attempt to evaluate the anticarcinogenic property of Muntingia Calabura proteins against Oral cancer cell lines. Oral cancer cell lines (KB cell line) were used in the present study. The proteins were extracted from Muntingia Calabura roots and the antiproliferative and cytotoxic activity on KB cell line was evaluated using 3-(4,5-dimethylthiazol-2-YL)-2,5-diphenyl tetrazolium bromide assay. The crude proteins of Muntingia Calabura roots showed cytotoxic and anti-proliferative activity on KB cell lines at a maximum efficacy at $100 \mu \mathrm{g} / \mathrm{Ml}$ is about $58 \%$ and maximum IC50 value is $52 \mu \mathrm{g} / \mathrm{Ml}$. The crude proteins of Muntingia Calabura roots effective as an antiproliferative agent, who caused apoptosis in oral cancer cell line.

Keywords: Muntingia Calabura, plant proteins, oral cancer, squamous cell carcinoma, KB cell lines.

Copyright @ 2019: This is an open-access article distributed under the terms of the Creative Commons Attribution license which permits unrestricted use, distribution, and reproduction in any medium for non-commercial use (NonCommercial, or CC-BY-NC) provided the original author and sources are credited.

\section{INTRODUCTION}

In oral cancer, the squamous cell carcinoma (SCC) is the very common type of cancer with high rate of mortality and morbidity [1, 2]. In the Indian subcontinent, the oral cancer is occupied the $6^{\text {th }}$ position [3]. Various bad habits like chewing of tobacco, betel quid, areca nut $[4,5]$ and even the infection of human papilloma virus (HPV) also increase the risk factor of Oral Cancer [6, 7]. Though the pharmaceutical industries are developing more potent anticancer drugs with the help of researchers, the conventional treatments such as surgery, radiotherapy and chemotherapy, problems related to these therapies such as side effects, opportunistic infections and the development of drug resistance remained unsolved [8, 10]. Hence, there is an urgency to develop novel treatment ways using plant derivatives which act as effective therapeutic agents and have minimal / no side effects.

Many studies have shown that the different solvent extracts of Muntingia Calabura can inhibit /prevent different types of Cancers. Proteins of
Muntingia Calabura plant root is one such natural anticancerous plant product, whose anticancer effect $n$ oral cancer has never been reported. Herein the study was designed for the in vitro apoptotic effect of Muntingia Calabura plant root proteins on SCC cancer cells.

\section{MATERIALS AND METHODS Preparation of Extracts}

$10 \mathrm{~g}$ of fresh roots of Muntingia Calabura plant were collected from local area, washed thoroughly with distilled water, cut in to small pieces and crushed with $200 \mathrm{ml}$ of double distilled water. Further vortexed for two hours at room temperature, was centrifuged at $10000 \mathrm{rpm}$ at $4^{\circ} \mathrm{C}$ for 20 minutes. The supernatant collected was subjected to protein precipitation using 55\% Ammonium Sulphate. The mixture kept for vortex overnight at $10^{\circ} \mathrm{C}$. Further, the mixture was centrifuged at $10,000 \mathrm{rpm}$ using refrigerated centrifuge, the precipitated protein was collected. The collected ammonium sulphate protein precipitate was desalted using molecular cutoff centricons $(2 \mathrm{kDa})$. The salt free protein precipitate was stored in deep freezer for further 
analysis. Five concentrations of 5, 10, 15, 20 and $25 \mu \mathrm{g}$ of proteins were prepared.

\section{Cell Line and Cell Culture}

Oral SCC cell line (KB mouth cell line) procured from the National Centre for Cell Sciences, Pune, India for the study. The KB mouth cell line was seeded into a 96 well microtiter plate containing Eagle Minimum Essential Medium supplemented with fetal bovine serum (10\%) and penicillin (1\%) and streptomycin. With 5\% humidity, the cells were maintained in a $\mathrm{CO}_{2}$ incubator at $37^{\circ} \mathrm{C}$ for 48 to $72 \mathrm{~h}$.

\section{Activity of Extracts on Oral Cancer Cell Line}

After the incubation ( 24 hours), the seeded oral SCC cell lines (KB mouth cell line) in 96- well plates at a density of $5 \times 10^{4}$ cells/well, were treated with crude proteins of Muntingia Calabura plant root of five concentrations viz 5, 10, 15, 20 and $25 \mu \mathrm{g} / \mathrm{mL}$ diluted with dimethyl sulfoxide (DMSO) and incubated for 24 to 48 hours. Based on the mitochondrial dehydrogenase activity in the living cells, the proliferation activity of cell population under different concentrations was determined.

\section{Cell Viability Assay}

The Cell viability assay was done to determine the sublethal concentrations of inhibitory concentration (IC50) and proliferative activity of the cells in the presence of crude proteins of Muntingia Calabura plant root. After the completion of incubation period, working solution $10 \mu \mathrm{l}$ of 3-(4,5-dimethylthiazol-2YL)-2,5-diphenyltetrazolium bromide was added to each culture well to detect the cell viability. The color was allowed to develop for an additional 4 hours of incubation. Equal volume of DMSO was added to stop this reaction to solubilize the crystals. Absorbance was recorded at $570 \mathrm{~nm}$ using Shimadzu UV-Visible spectrophotometer [11].

\section{STATISTICAL ANALYSIS}

The data are given as the mean \pm standard deviation (SD). The statistical analysis was performed by using one-way analysis of variance (ANOVA), followed by a Dunnett's multiple-comparison test with 95\% confidence intervals. A P-value $<0.01$ was considered to indicate a statistically significant difference.

\section{RESULTS}

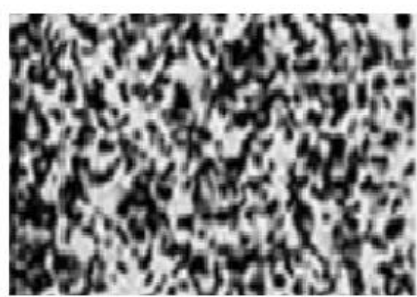

Oral squamous cell lines

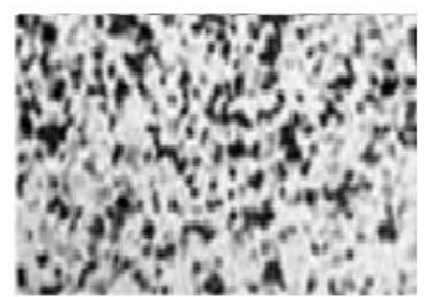

Muntigia Calabura proeins showing inhibition at $100 \mathrm{ug} / \mathrm{ml}$ after $24 \mathrm{~h}$

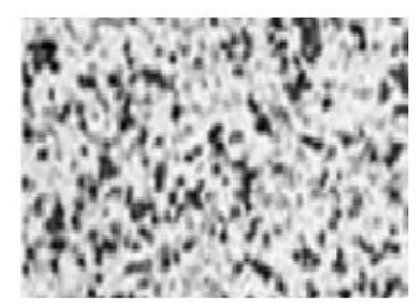

Muntigia Calabura proeins showing inhibition at $100 \mathrm{ug} / \mathrm{ml}$ after $48 \mathrm{~h}$

Fig-1: KB cell lines as control, and the apoptotic activities of crude proteins of Muntingia Calabura plant root against KB cell lines at 50ug and 100ug/ml

The crude proteins of Muntingia Calabura plant root proteins showed antitumor activity against $\mathrm{KB}$ cell line. The viability decreased in a dosedependent manner. The cell viability decreased as the concentration of the extracts increased. The proteins exhibited their efficacy at $100 \mu \mathrm{g} / \mathrm{mL}$ by killing $58 \%$ of cells (Figure-1). The IC50 values were also calculated, as the crude proteins of Muntingia Calabura plant proteins showed a maximum IC50 at $52 \mu \mathrm{g} / \mathrm{mL}$. Similar studies have been done using Almond, Apricot extract and Berberine a natural isoquinoline alkaloid isolated from plant genus Coptis [12, 13]. The viability decreased in a dose-dependent manner. The crude proteins also showed a promising cytotoxic efficacy.

Table-1: The percentage of cell population in different period of time (Cytotoxicity studies)

\begin{tabular}{|l|l|l|}
\hline Percentage & 24 Hours & 48 Hours \\
\hline Live & 84.11 & 27.12 \\
\hline Apoptosis & 41.04 & 38.31 \\
\hline Late apoptosis & 25.02 & 50.22 \\
\hline
\end{tabular}

\section{DISCUSSION}

It is reported that, the different parts of Muntigia Calabura plant contains significant amount of proteins, tannins, alkaloids, steroids and flavonoids. The methanol extract of Muntingia Calabura plant showed antifouling and anti microbial activity in different model systems [14]. Further, it is reported that, the aqueous leaf extract of Muntingia Calabura plant at concentrations of $10 \%, 50 \%$ and $100 \%$ showed significant antinociceptive, anti-inflammatory and antipyretic activities [15]. It is reported that, the extracts of roots, leaves and fruits of Muntingia Calabura plant showing excellent antioxidant activities in different model systems [16]. It is reported that, the flavonoid rich methonolic extract of Muntingia calabura plant leaves showed anticarcinogenic activity against the azoxymethane-induced colon cancer in rats involved modulation of the colonic antioxidant system [17]. Furthermore, it is reported that, the antinociceptive activity of MEMC involved activation of the nonselective opioid (particularly the $\mu-, \delta$ - and $\kappa$-opioid) 
and non-opioid (particularly adenosinergic, $\alpha_{2}$ noradrenergic, and $\beta$-adrenergic) receptors, modulation of the ATP-sensitive $\mathrm{K}^{+}$channel, and inhibition of bradikinin and protein kinase $\mathrm{C}$ actions. The discrepancies in MEMC antinociception could be due to the presence of various phytochemicals [18]. With all the above surveys, it was noticed by us is that, no scientific reports or studies are done using proteins isolated from roots of Muntingia Calabura plants. The obtained results are very promising and hence further more purification proteins are needed and the studies are continued in this direction.

\section{CONCLUSION}

Based on the results of our study and literature review, the crude proteins extracted from roots of Muntingia Calabura plant are showed cytotoxic effect on human oral cancer cell lines. However, purification of these proteins is ongoing to find the protein responsible for this anticancer property.

\section{REFERENCE}

1. Nóbrega, T. D., Salomão-Israel-MonteiroLourenço Queiroz, E., de Moura Santos, A. D. L., Costa, L., Pereira-Pinto, L., \& de Souza, L. B. (2018). Clinicopathological evaluation and survival of patients with squamous cell carcinoma of the tongue. Medicina oral, patologia oral $y$ cirugia bucal, 23(5), e579-e587.

2. Markopoulos, A. K. (2012). Current aspects on oral squamous cell carcinoma. The open dentistry journal, 6, 126-130.

3. Coelho, K. R. (2012). Challenges of the oral cancer burden in India. Journal of cancer epidemiology, 701932.

4. Niaz, K., Maqbool, F., Khan, F., Bahadar, H., Hassan, F. I., \& Abdollahi, M. (2017). Smokeless tobacco (paan and gutkha) consumption, prevalence, and contribution to oral cancer. Epidemiology and health, 39:e2017009.

5. Lee, C. Y., Wu, C. F., Chen, C. M., \& Chang, Y. Y. (2018). Qualitative study for betel quid cessation among oral cancer patients. PloS one, 13(7), e0199503.

6. Kim, S. M. (2016). Human papilloma virus in oral cancer. Journal of the Korean Association of Oral and Maxillofacial Surgeons, 42(6), 327-336.

7. Candotto, V., Lauritano, D., Nardone, M., Baggi, L., Arcuri, C., Gatto, R., ... \& Carinci, F. (2017). HPV infection in the oral cavity: epidemiology, clinical manifestations and relationship with oral cancer. ORAL \& implantology, 10(3), 209-220.

8. Huang, C. Y., Ju, D. T., Chang, C. F., Reddy, P. M., \& Velmurugan, B. K. (2017). A review on the effects of current chemotherapy drugs and natural agents in treating non-small cell lung cancer. Biomedicine, 7(4):23.
9. Casals, E., Gusta, M. F., Cobaleda-Siles, M., Garcia-Sanz, A., \& Puntes, V. F. (2017). Cancer resistance to treatment and antiresistance tools offered by multimodal multifunctional nanoparticles. Cancer nanotechnology, 8(1), 7.

10. Zheng, P. P., Li, J., \& Kros, J. M. (2018). Breakthroughs in modern cancer therapy and elusive cardiotoxicity: Critical research- practice gaps, challenges, and insights. Medicinal research reviews, 38(1), 325-376.

11. Mosmann, T. (1983). Rapid colorimetric assay for cellular growth and survival: application to proliferation and cytotoxicity assays. Journal of immunological methods, 65(1-2), 55-63.

12. Sireesha, D., Reddy, B. S., Reginald, B. A., Samatha, M., \& Kamal, F. (2019). Effect of amygdalin on oral cancer cell line: An in vitro study. Journal of oral and maxillofacial pathology: JOMFP, 23(1), 104-107.

13. Kim, J. S., Oh, D., Yim, M. J., Park, J. J., Kang, K. R., Cho, I. A., ... \& Kim, D. K. (2015). Berberine induces FasL-related apoptosis through p38 activation in KB human oral cancer cells. Oncology reports, 33(4), 1775-1782.

14. Singh, R., Iye, S., Prasad, S., Deshmukh, N., Gupta, U., Zanje, A., ... \& Joshi, S. (2017). Phytochemical Analysis of Muntingia calabura Extracts Possessing Anti-Microbial and AntiFouling Activities. International Journal of Pharmacognosy and Phytochemical Research, 9(6), 826-832.

15. Zakaria, Z. A., Hazalin, N. M. N., Zaid, S. M., Ghani, M. A., Hassan, M. H., Gopalan, H. K., \& Sulaiman, M. R. (2007). Antinociceptive, antiinflammatory and antipyretic effects of Muntingia calabura aqueous extract in animal models. Journal of Natural Medicines, 61(4), 443448.

16. Nagara, B. G. (2015). Antioxidant Activity: Root, Leaves and Fruits Aqueous Extracts of MuntingiaCalabura. Journal of Innovations in Pharmaceuticals and Biological Sciences, 2(4):363-368.

17. Md Nasir, N. L., Kamsani, N. E., Mohtarrudin, N., Othman, F., Md. Tohid, S. F., \& Zakaria, Z. A. (2017). Anticarcinogenic activity of Muntingia calabura leaves methanol extract against the azoxymethane-induced colon cancer in rats involved modulation of the colonic antioxidant system partly by flavonoids. Pharmaceutical biology, 55(1), 2102-2109.

18. Zakaria, Z. A., Sani, M. H. M., Cheema, M. S., Kader, A. A., Kek, T. L., \& Salleh, M. Z. (2014). Antinociceptive activity of methanolic extract of Muntingia calabura leaves: further elucidation of the possible mechanisms. BMC complementary and alternative medicine, 14(1), 63. 